\title{
CDK6 Gene Mutation
}

National Cancer Institute

\section{Source}

National Cancer Institute. CDK6 Gene Mutation. NCI Thesaurus. Code C157380.

A change in the nucleotide sequence of the CDK6 gene. 